EUROPA REGIONUM TOM XXII ROK 2015

DOI: $10.18276 /$ er.2015.22-03

Milena ANNA Bera

Szczecin

\title{
Obszary chronione Natura 2000 z perspektywy społeczności lokalnych w Polsce północno-wschodniej"
}

\section{Wprowadzenie}

posób postrzegania i ujmowania walorów przyrodniczych - w tym obsza$D$ rów chronionych Natura 2000 w lokalnej polityce rozwoju zależy od wielu czynników. Do najistotniejszych należy zaliczyć poziom kapitału społecznego, świadomość ekologiczną mieszkańców, lokalnych liderów, aktywność samorządów lokalnych w projektach realizowanych na obszarach cennych przyrodniczo. Nie mniej jednak, 10 lat po wyznaczeniu pierwszych obszarów Europejskiej Sieci Ekologicznej Natura 2000, w Polsce kojarzy się ona z nakazami i zakazami oraz ograniczeniami inwestycyjnymi.

W artykule zaprezentowano wyniki badań ankietowych przeprowadzonych wśród samorządów terytorialnych gmin Polski północno-wschodniej, których obszar co najmniej w 50\% został objęty programem Natura 2000. Do badania zakwalifikowano 47 gmin, głównie wiejskich o charakterze rolniczym. Kwestionariusze ankietowe wypełniały osoby mające wpływ na podejmowane w gminie decyzje. Stopień zwrotu ankiet wyniósł $100 \%$.

Obszary chronione Natura 2000 w ocenie samorządów terytorialnych badanych gmin.

* Praca naukowa sfinansowana ze środków na naukę w latach 2010-2012 jako projekt badawczy. 
Społeczności lokalne, zamieszkujące i gospodarujące na terenach Natura 2000, często formułują zarzut, iż dla spełnienia zasady sprawiedliwości międzygeneracyjnej poświęca się sprawiedliwość wewnątrzpokoleniową, wymagając od mieszkańców tych terenów wyrzeczeń i niższego poziomu rozwoju społeczno-gospodarczego ${ }^{1}$. Niewątpliwie zasada sprawiedliwości międzygeneracyjnej jest jedną z podstawowych zasad zrównoważonego rozwoju. Koncepcja ta wiąże nierozerwalnie zachowanie zasobów przyrody dla przyszłych pokoleń z koniecznością wzrostu jakości życia i rozwojem gospodarczym. Składa się $z$ trzech niezależnych od siebie elementów: ekonomicznych, społecznych i środowiskowych. Wymaga zatem działania we wszystkich trzech kierunkach, na różnych poziomach: lokalnym, powiatowym, wojewódzkim, państwowym i światowym ${ }^{2}$.

W związku z tym przedstawiciele badanych gmin, których obszar w co najmniej 50\% został objęty programem Natura 2000, zostali poproszeni o opowiedzenie się w ankiecie za pozostawieniem lub ograniczeniem na terenie gminy obszarów Natura 2000.

1 P. Legutko-Kobus, Możliwość gospodarowania na obszarach chronionych - analiza geograficzno-ekonomiczna, materiały pokonferencyjne „Obszary chronione w gminie: przeszkody we wzroście gospodarczym czy szansa na zrównoważony rozwój”, Supraśl 2012.

2 H. Adamska, Teoria i praktyka zrównoważonego rozwoju, w: Wdrażanie koncepcji zrównoważonego rozwoju w gminie Kostomtoty, red. A. Grabarczyk, Wydawnictwo EkoPress, Wrocław-Białystok 2007, s. 7. 


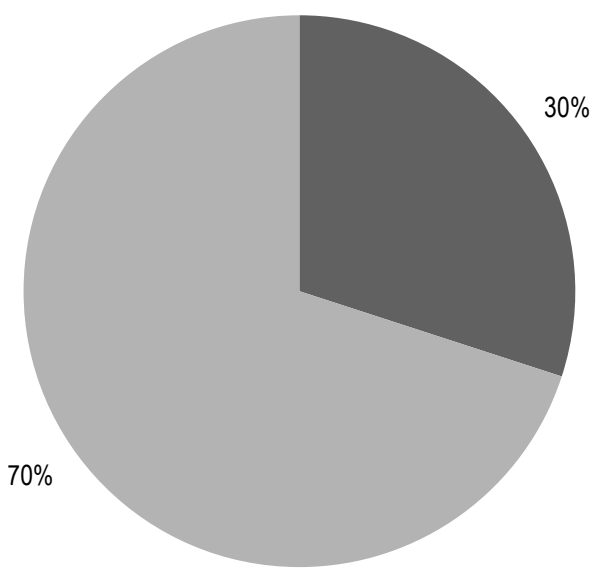

- pozostawienie obszarów Natura 2000 w gminie w obecnym kształcie

ograniczenie obszarów Natura 2000

Rys. 1. Opinia władz lokalnych na temat sieci Natura $2000 \mathrm{w}$ badanych gminach

Źródło: opracowanie własne na podstawie badań ankietowych wśród samorządów lokalnych gmin.

Jak wynika z przeprowadzonych badań większość przedstawicieli samorządów terytorialnych $-70 \%$ jest zdania, iż obszary Natura 2000 powinny zostać w gminie ograniczone. Zaledwie 30\% badanych postuluje pozostawienie obszarów Natura 2000 w obecnym kształcie. Należy przy tym pamiętać, że tak, jak powołanie obszaru Natura 2000, tak i jego likwidacja może nastąpić tylko i wyłącznie na podstawie argumentów merytorycznych, świadczących o zachodzeniu w granicach danego obszaru naturalnych zmian przyrodniczych, eliminujących przedmioty ochrony danego obszaru Natura 2000. Dane, które to potwierdzą, muszą pochodzić $\mathrm{z}$ wieloletniego monitoringu danego obszaru i z informacji związanych z nadzorem nad tym obszarem. Na likwidację obszaru, a nawet na zmianę jego granic musi wyrazić zgodę Komisja Europejska ${ }^{3}$. Samorządy lokalne zdają sobie sprawę z tego, iż ustanowienie Europejskiej Sieci Ekologicznej Natura 2000 jest obowiązkiem każdego z krajów członkowskich Unii Europejskiej, mimo to jak pokazało badanie w większości są negatywnie nastawione do sieci Natura 2000. W związku z tym respondenci zostali popro-

3 DzU 2004, nr 92, poz. 880, Ustawa z dnia 16 kwietnia 2004 o ochronie przyrody. 
szeni o wskazanie negatywnych efektów funkcjonowania obszarów Natura $2000 \mathrm{w}$ gminie.

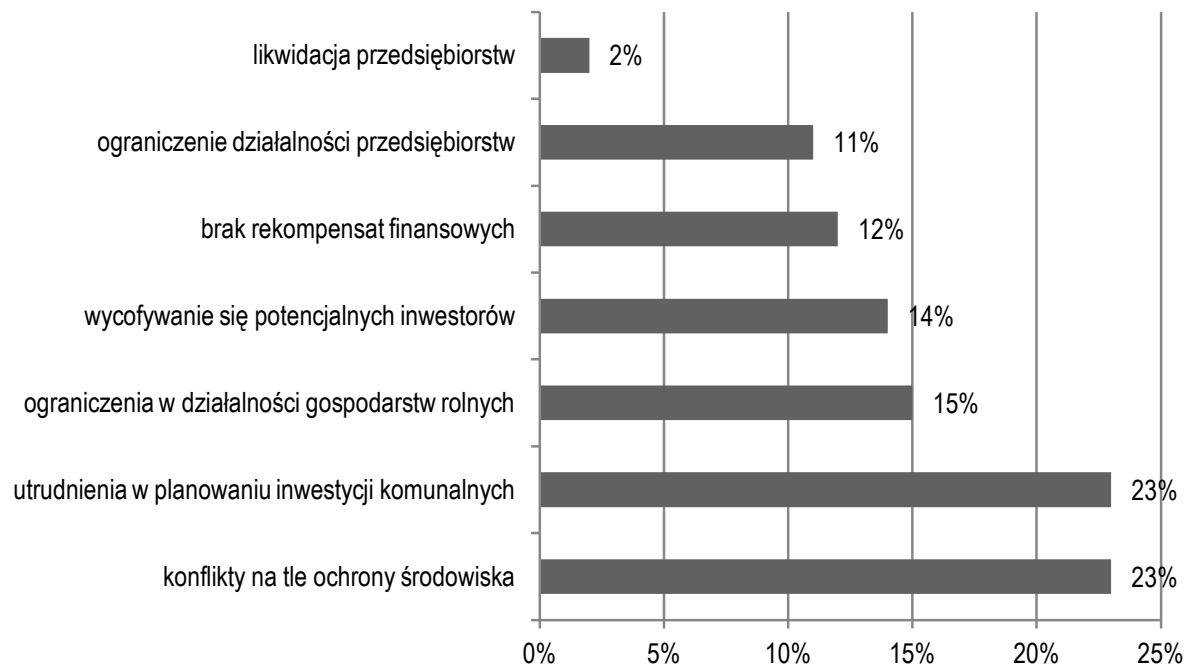

Rys. 2. Negatywne efekty funkcjonowania obszarów Natura 2000 według respondentów $(\%)$

Źródło: opracowanie własne na podstawie badań ankietowych wśród samorząáw lokalnych gmin.

Negatywnymi efektami, jakie zaobserwowali respondenci na terenie objętym siecią są głównie problemy związane z prowadzeniem działalności gospodarczej. Najczęściej zwracano uwagę na utrudnienia w planowaniu i realizacji inwestycji komunalnych, konflikty na tle ochrony środowiska (23\% respondentów) oraz ograniczenia $\mathrm{w}$ działalności gospodarstw rolnych $-15 \%$. W dalszej kolejności wskazywano na wycofywanie się potencjalnych inwestorów, brak rekompensat za utracone korzyści z tego tytułu oraz ograniczenie działalności przedsiębiorstw, to główne negatywne aspekty funkcjonowania sieci Natura 2000. Podkreślono również wyraźnie fakt, pojawienia się konfliktów na tle ochrony środowiska (17\% respondentów). Konflikty te często są wynikiem braku odpowiedniej informacji na temat funkcjonowania obszarów Natura 2000. W odróżnieniu od innych obszarów chronionych, dozwolona jest tutaj każda 
działalność, która nie wpływa znacząco negatywnie na przedmiot ochrony ${ }^{4}$. Jakkolwiek wzrost kosztów planowania i realizacji inwestycji jest nieunikniony, to zasadnym jest optymalizowanie rozwiązań w sposób uwzględniający nie tylko koszty realizacji inwestycji, ale przede wszystkim w sposób pozwalający na optymalny dobór urządzeń i rozwiązań chroniących środowisko. Ostatecznie to właśnie jakość i czas życia rozwiązań, chroniących środowisko przy realizacji inwestycji infrastrukturalnych w Polsce, będzie wyznaczać standard życia przyszłych pokoleń w harmonii człowieka ze środowiskiem. W związku z tym władze lokalne dostrzegają oprócz negatywnych stron również pozytywne efekty funkcjonowania sieci Natura 2000 na terenie gminy.

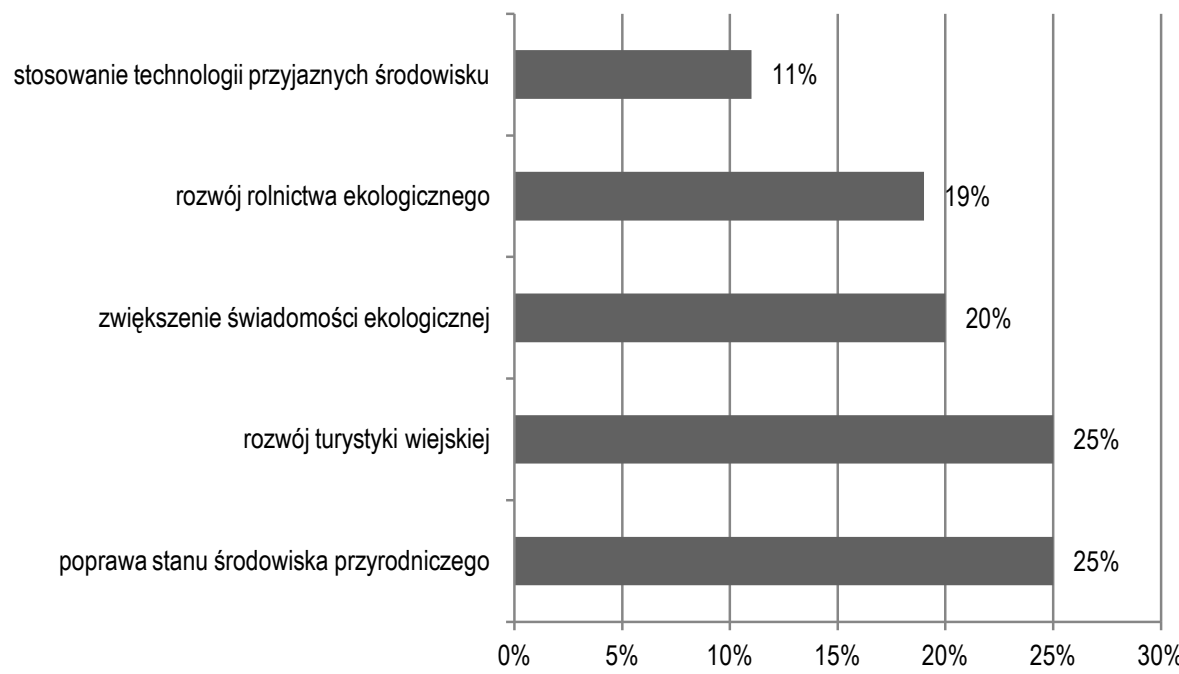

Rys. 3. Pozytywne efekty funkcjonowania obszarów Natura 2000 według respondentów (\%)

Źródło: opracowanie własne na podstawie badań ankietowych wśród samorządów lokalnych gmin.

Pozytywnymi aspektami, jakie zaobserwowano są poprawa stanu środowiska przyrodniczego oraz rozwój turystyki wiejskiej (25\% respondentów). W mniejszym stopniu zwrócono uwagę na zwiększenie świadomości ekolo-

4 J. Jarosik, Kompendium wiedzy o sieci Natura 2000 dla samorządu, Wydawca Generalna Dyrekcja Ochrony Środowiska, Warszawa 2013, s. 95. 
gicznej mieszkańców - 20\% oraz rozwój rolnictwa ekologicznego - 19\%. Zaledwie $10 \%$ respondentów zaobserwowało wprowadzenie w przedsiębiorstwach technologii przyjaznych środowisku.

Reasumując wypowiedzi respondentów na temat barier i czynników rozwojowych gmin, wynikających $\mathrm{z}$ utworzenia na ich terenie obszarów chronionych Natura 2000, można stwierdzić, iż dostrzegają oni z jednej strony pozytywne efekty w postaci właściwego gospodarowania zasobami i walorami środowiska przyrodniczego, $\mathrm{z}$ drugiej zaś strony podają wiele zarzutów natury gospodarczej i proceduralnej, co przekłada się na ograniczenie budżetów gmin i trudności w zaspokajaniu potrzeb inwestycyjnych. 74\% ankietowanych twierdzi, że objęcie gminy siecią Natura 2000 nie miało wpływu na sytuację finansową gminy, natomiast $36 \%$ ankietowanych uważa przeciwnie. Co ciekawe, ci sami ankietowani zapytani o to, czy ich zdaniem z tytułu objęcia części gminy siecią Natura 2000 powinny być przyznane gminie dodatkowe środki finansowe aż w $95 \%$ byli zdania, że jak najbardziej tak. Cel, na jaki zostałyby one wydatkowane, to w przeważającej większości, infrastruktura ochrony środowiska.

Respondenci widzą ograniczenia związane $\mathrm{z}$ objęciem części gminy siecią Natura 2000 głównie w odniesieniu do lokalnej gospodarki, wymieniając przede wszystkim ograniczenia w działalności gospodarczej, takie jak zwiększenie kosztów prowadzenia działalności, ograniczenie inwestycji na terenach turystycznych. Z drugiej strony $97,5 \%$ badanych nie stwierdziło po wprowadzeniu sieci Natura 2000 na obszarze gminy, sytuacji w której lokalne podmioty gospodarcze zlikwidowały bądź przeniosły swoją działalność. 32\% respondentów widzi ograniczenia odnośnie możliwości działań samorządu terytorialnego. Wskazują oni na wydłużenie procedur administracyjnych, zwiększenie wymagań w zakresie Oceny Oddziaływania na Środowisko, ograniczenie samodzielności władz gminnych.

W stosunku do lokalnej społeczności, 24,5\% przedstawicieli gmin zauważa trudności w korzystaniu z gruntów i ograniczenia w dysponowaniu własnością. Jednocześnie tylko połowa badanych angażuje się w wyjaśnianie mieszkańcom spraw związanych z funkcjonowaniem sieci Natura 2000, organizując spotkania indywidualne i grupowe. W związku z tym większość ankietowanych opowiada się z ograniczeniem obszarów Natura 2000 w gminie. Za ważny argument podają brak uwzględnienia uwag władz lokalnych zgłaszanych w konsultacjach społecznych dotyczących wyznaczania obszarów Natura 2000. Za pozytywny aspekt funkcjonowania sieci Natura 2000 podają głównie poprawę 
stanu środowiska przyrodniczego, rozwój rolnictwa ekologicznego, wprowadzanie przez przedsiębiorców technologii produkcji przyjaznych środowisku oraz rozwój turystyki wiejskiej.

Czynniki niezbędne do prawidłowego funkcjonowania sieci Natura 2000.

$\mathrm{Na}$ podstawie analizy dostępnej literatury oraz przeprowadzonych badań można wskazać cztery główne czynniki niezbędne do prawidłowego funkcjonowania sieci Natura $2000 \mathrm{w}$ przestrzeni społeczno-gospodarczej ${ }^{5}$ :

1. Instrumenty prawne.

2. Rozwiązania organizacyjne i zarządzanie na różnych poziomach.

3. Akceptacja społeczna.

4. Środki finansowe.

Na tle poziomu prawa stanowionego w Polsce legislacja dotycząca Natury 2000 przedstawia się zadowalająco, chociaż wydaje się, że krajowe akty prawne implementują rozwiązania unijne z przesadną zachowawczością. Unia Europejska w dyrektywach dotyczących Natury 2000 zawarła bowiem jedynie bardzo ogólne zapisy, wytyczające pewne kierunki, a nie zobowiązujące do przyjęcia konkretnych rozwiązań. Może to być jednak źródłem pewnych wątpliwości w procesie interpretacji i stosowania prawa. Pod względem organizacyjnym, zarówno instytucje zarządzające ochroną przyrody, jak i narzędzia planistyczne dla obszarów sieci, tworzone są z dużym opóźnieniem w stosunku do wprowadzenia Natury 2000 w Polsce. Nadal niejasna jest kwestia rzeczywistego, a nie tylko formalnego podziału kompetencji, obowiązków i odpowiedzialności w procesie zarządzania obszarami Natura 2000. Ponadto zaniedbana sfera komunikacji społecznej, owocuje nieufnością, obawami i niechęcią wobec nowej formy przyrody. Należy rozważyć szersze wdrożenie instrumentów rekompensat oraz wskazanie jednostkom samorządowym i podmiotom gospodarczym nowych możliwości rozwoju. Dotychczasowe doświadczenia wskazują, że realizacja celów ochrony przyrody jedynie drogą zakazów i ograniczeń jest mało skuteczna $\mathrm{w}$ przeciwieństwie do połączenia rozwiązań prawnych $\mathrm{z}$ systemem zachęt ekonomicznych na zasadach dobrowolności, popartych edukacją. To zintegrowane podejście do zagadnienia ochrony wymaga jednak większych nakładów m.in. na rekompensaty i zarządzanie siecią.

5 A. Bołtromiuk, Możliwości i problemy rozwoju obszarów wiejskich objętych siecia ekologiczna Natura 2000 - podsumowanie i rekomendacje, w: Europejska sieć ekologiczna Natura 2000 jako nowy element otoczenia polskiej wsi i rolnictwa, red. A. Bołtromiuk, Wydawnictwo IRWiR PAN, Warszawa 2010, s. 254-282. 


\section{Podsumowanie}

Szans dla rozwoju badanych gmin należy upatrywać w zmianie sposobu myślenia o obszarach ochrony przyrody i udziale społeczeństwa w podejmowaniu istotnych decyzji ich dotyczących. Często wymienianą barierą jest ogólna dezinformacja i niepewność co do obowiązujących przepisów i konkretnych ograniczeń związanych z siecią Natura 2000.

Obszary chronione powinny być postrzegane nie tylko jako obszary nakierowane na ochronę przyrody, ale również służące celom społecznym, ekonomicznym i kulturowym. Na pierwszy plan wysuwa się tutaj modelową rolę obszarów chronionych jako wzoru zrównoważonego rozwoju, łączącego w sobie ochronę cennych ekosystemów, odtwarzanie ekosystemów całkowicie lub częściowo zniszczonych lub możliwie najmniej szkodzący rozwój społeczno-gospodarczy stymulowany przez istniejące walory przyrodnicze. Powinno podkreślać się dużą rolę współdziałania różnych podmiotów w zarządzaniu obszarami ochrony przyrody: samorządów lokalnych, przedsiębiorców, rządu, organizacji samorządowych. Lokalne społeczności nie powinny być traktowane jako bierni odbiorcy odgórnych wytycznych i zakazów, a raczej jako ekonomiczni i kulturalni beneficjenci obszarów chronionych oraz aktywni partnerzy włączający się w funkcjonowanie obszaru chronionego.

Zmiany legislacyjne w Polsce spowodowały, że bez zgody lokalnych samorządów, niemożliwe jest utworzenie lub rozszerzenie obszarów chronionych, w tym obszarów Natura 2000. Wiąże się to z większym niż dotychczas uwzględnieniem potrzeb i wymagań lokalnych społeczności w funkcjonowaniu, w tym zwróceniem większej uwagi na ekonomiczną i kulturotwórczą rolę tych obszarów. Z drugiej strony istnieje obawa, że uwzględniając wymagania lokalnych społeczności, dotyczące głównie rozwoju ekonomicznego, zagrozi to dobrom przyrodniczym. Aby pogodzić obie tendencje należy zastanowić się, jak powinny być kształtowane relacje pomiędzy obszarami chronionymi a lokalnymi społecznościami oraz wpływ tych obszarów na zrównoważony rozwój.

Bardzo ważny jest stopień świadomości ekologicznej i akceptacja obszarów chronionych przez mieszkańców gmin. Jeżeli społeczeństwo nie widzi korzyści dla siebie z istnienia obszarów chronionych, nie ma dostatecznej świadomości konieczności ochrony przyrody, ich ochrona jest utrudniona. 


\title{
Literatura
}

Adamska H., Teoria i praktyka zrównoważonego rozwoju, w: Wdrażanie koncepcji zrównoważonego rozwoju w gminie Kostomłoty, red. A. Grabarczyk, Wydawnictwo EkoPress, Wrocław-Białystok 2007.

Bołtromiuk A., Możliwości i problemy rozwoju obszarów wiejskich objętych sieciq ekologiczna Natura 2000 - podsumowanie i rekomendacje, w: Europejska sieć ekologiczna Natura 2000 jako nowy element otoczenia polskiej wsi i rolnictwa, red. A. Bołtromiuk, Wydawnictwo IRWiR PAN, Warszawa 2010.

Jarosik J., Kompendium wiedzy o sieci Natura 2000 dla samorzadu, Wydawca Generalna Dyrekcja Ochrony Środowiska, Warszawa 2013.

Legutko-Kobus P., Możliwość gospodarowania na obszarach chronionych - analiza geograficzno-ekonomiczna, materiały pokonferencyjne „Obszary chronione w gminie: przeszkody we wzroście gospodarczym czy szansa na zrównoważony rozwój”, Supraśl 2012.

Ustawa z dnia 16 kwietnia 2004 o ochronie przyrody (DzU 2004, nr 92, poz. 880).

\section{Natura 2000 European protected areas from the perspective of local communities in north-eastern Poland}

\begin{abstract}
Summary
The perception of natural values - including the Nature 2000 protected areas in the local development policy depends on many factors. The most important are the level of social capital, environmental awareness of inhabitants, local leaders, local government activity in projects carried in areas of high natural value. Nevertheless, 10 years after determining the first areas of the European ecological network Nature 2000 in Poland still associate it with the commands and prohibitions and restrictions of investment. The article presents the results of surveys conducted among local governments municipalities in north-east, Poland where the area of at least $50 \%$ is covered by the Nature 2000 program. The study included 47 municipalities, mostly rural of agricultural character. Survey questionnaires filled people who have influence on the decisions taken in the community, The degree of survey return was $100 \%$.
\end{abstract}

Keywords: protected areas Nature 2000, local self-government, sustainable development, environmental awareness.

Translated by Milena Anna Bera 